Paideusis

\title{
“That's Just Your Opinion!” - “American Idol” and the Confusion Between Pluralism and Relativism
}

\section{Claudia W. Ruitenberg}

Volume 16, Number 1, 2007

URI: https://id.erudit.org/iderudit/1072607ar

DOI: https://doi.org/10.7202/1072607ar

See table of contents

Publisher(s)

Canadian Philosophy of Education Society

ISSN

0838-4517 (print)

1916-0348 (digital)

Explore this journal

Cite this article

Ruitenberg, C. (2007). “That’s Just Your Opinion!” - “American Idol” and the Confusion Between Pluralism and Relativism. Paideusis, 16(1), 55-59.

https://doi.org/10.7202/1072607ar
Article abstract

Many student-teachers (and the students they teach) fail to understand the difference between opinions in the sense of preferences, and opinions in the sense of judgments. The phrase "That's just your opinion!" (as wielded by contestants on the television series "American Idol") is used to shield not only preferences but also judgments from public scrutiny. This misunderstanding springs from confusion between pluralism and relativism. Students' fear of moral absolutism leads them to espouse relativism when they should be promoting pluralism. Within a conception of education as a social practice that mediates between the private and the public, students must learn both to justify their own judgments and to examine the judgments and justifications that others provide. This requires that students learn to distinguish "just my opinion" and "just your opinion" from morally significant judgments.
This document is protected by copyright law. Use of the services of Erudit (including reproduction) is subject to its terms and conditions, which can be viewed online.

https://apropos.erudit.org/en/users/policy-on-use/ 


\title{
"That's Just Your Opinion!" - "American Idol" and the Confusion Between Pluralism and Relativism
}

\author{
CLAUDIA W. RUITENBERG \\ University of British Columbia, Canada
}

\begin{abstract}
Many student-teachers (and the students they teach) fail to understand the difference between opinions in the sense of preferences, and opinions in the sense of judgments. The phrase "That's just your opinion!" (as wielded by contestants on the television series "American Idol") is used to shield not only preferences but also judgments from public scrutiny. This misunderstanding springs from confusion between pluralism and relativism. Students' fear of moral absolutism leads them to espouse relativism when they should be promoting pluralism. Within a conception of education as a social practice that mediates between the private and the public, students must learn both to justify their own judgments and to examine the judgments and justifications that others provide. This requires that students learn to distinguish "just my opinion" and "just your opinion" from morally significant judgments.
\end{abstract}

Those of you who, like me, watch too much junk TV may have come across a phenomenon called "American Idol." In this "reality" television series thousands of people between the ages of 16 and 28 audition in a singing contest, in the hopes of becoming "the next American idol" and winning a music contract. The opening episodes of each series feature many contestants who believe they sing wonderfully well, but who are tone deaf, randomly jump from key to key in the short song fragment they perform, or who produce sounds not associated with "singing" even in the broad sense of the word. Some of these contestants receive the feedback of the judges graciously; many others, however, show indignation at a negative evaluation. A commonly heard response to such a negative evaluation is, "That's just your opinion!"

Whatever the psychological explanations for this defensive response may be, in a philosophical sense “That's just your opinion!" expresses confusion between a preference and a judgment. Unfortunately, this confusion extends far beyond "American Idol." One of the factors contributing to this confusion is that in our everyday language, the word "opinion" can refer both to a preference and to a judgment. If someone asks me, "What is your opinion about the new leader of the Liberal Party?" I assume I am expected to provide a judgment for which I have reasons. When contestants on "American Idol" say, "That's just your opinion!" they typically mean, "That is merely a personal preference, for which you have no reasons!"

From the teacher education courses I have taught, including, most recently, Critical Thinking, I have the impression that many student-teachers (as well as many of the students they teach) share the confusion about preferences and judgments. A major contributing factor to this confusion, I surmise, is the popular idea that: "Everyone is entitled to her or his opinion." When it comes to mere preferences

(C) Copyright 2007. The author, Claudia Ruitenberg, assigns to Paideusis the right of first publication and educational and nonprofit institutions a non-exclusive license to use this document for personal use and in courses of instruction provided that the article is used in full and this copyright statement is reproduced. Any other usage is probibited without the express permission of the author. 
such as my preference for dark over white chocolate, or someone else's preference for writing at night rather than during the daytime, I share the idea that everyone is entitled to her or his preferences and that, as is implied by this idea, people should not be required to justify these preferences. When it comes to judgments, however, it is a different story.

If our students believe that everyone is entitled to her or his judgments, i.e., that people have a right to form whatever judgments they wish and that others have no right to question those judgments, they have moved into the territory of relativism. In the case of "American Idol," we are confronted with aesthetic relativism, the belief that there are no objective or intersubjective criteria for aesthetic quality and that what counts as aesthetic quality is entirely dependent on one's framework or perspective. Aesthetic relativism conflates aesthetic judgments with aesthetic preferences: "My singing is good because my mother likes it."

In our classrooms, we may encounter aesthetic relativism, but also other relativisms, such as moral relativism. Moral relativism is the belief that there are no objective or even intersubjective criteria for morality and that what counts as "moral" is entirely dependent on one's framework or perspective. For some of you, alarm bells may be ringing at this point. "What is she getting at? She is not seriously going to argue, in our 'postmodern condition' (Lyotard, 1979/1984), that there are universal moral truths, is she?!" No, I am not going to argue that there are universal moral truths. What I am going to argue, however, is that many of our students fail to understand the difference between pluralism and relativism, and that their fear of moral absolutism leads them to espouse relativism when they should be promoting pluralism.

Pluralism is the view that there is more than one set of values that is legitimate and worth pursuing, but not an infinite number. We might say that most of us show ourselves to be pluralists in our individual lives as we espouse a range of values, some of which are at odds with each other, such as justice and mercy. The question of pluralism is raised most often, however, about societies in which individuals and groups with different sets of values seek to cohabit. Isaiah Berlin (1998), a well-known champion of pluralism, writes:

If pluralism is a valid view, and respect between systems of values which are not necessarily hostile to each other is possible, then toleration and liberal consequences follow, as they do not either from monism (only one set of values is true, all the others are false) or from relativism (my values are mine, yours are yours, and if we clash, too bad, neither of us can claim to be right).

Berlin is aware of the impossibility of fixing once and for all how many sets of values ought to be respected, and who should be the arbiters of this selection. In fact, it is likely that there will always be disagreement about the range of values. What matters in pluralism, however, is that an ongoing conversation about the boundaries of the moral is maintained, and that this conversation meets certain criteria, perhaps most importantly that the interlocutors understand the difference between preferences and judgments, that they provide reasons for their judgments, and that all judgments and reasons are open to interrogation by others.

Blake, Smeyers, Smith and Standish (1998) explain moral relativism as: "the view that there are no objective moral or ethical standards, that each must live according to her own lights and, most fundamentally, each is immune to moral critique by others" (p. 9). The kind of relativism I have described above, which rejects not only objective but even intersubjective criteria, is a particularly pernicious and popular variety of relativism that Blake et al. call "subjectivism" (p. 12). Subjective relativism fails to distinguish between contingent and arbitrary moral standards; it treats all historically or culturally contingent moral standards as arbitrary, and hence rejects them as any standard at all. Judging a particular act—say, sexual intercourse with a woman against her will- to be immoral is based on a moral standard, in this case one of individual bodily integrity. I may well recognize this moral standard to be based on cultural conventions in which women and men are considered worthy of equal moral 
concern, and in which an individual woman has the right to protect her body from unwanted bodily invasions by any person, regardless of her relation or kinship to that person, and so on and so forth. Recognizing this moral standard to be contingent on those cultural conventions-for which good reasons can be and have been provided - is not at all the same as recognizing this moral standard as arbitrary, based solely on personal preferences or wishes. An arbitrary moral standard would say, for example, that one cannot have sexual intercourse with a woman against her will if she is wearing a green skirt (but it's okay if she's wearing a red skirt). Considering such an arbitrary standard to be of equal value as the moral standard of bodily integrity is a serious mistake.

The mistake may spring from what Eamonn Callan (1997) calls "a tendency to attend only to what are usually the more tractable aspects of diversity - the outward trappings of ethnicity, say, or divergent lifestyles" (p. 207). Discussions about the contingency of "opinions" often revolve around questions of food and fashion, debating, for example, the consumption of shrimp versus crickets. "This is misleading," Callan points out, "because ethnic differences or variety of life-style can thrive alongside an amicable moral unanimity, and ethnic commonality and convergent life-styles may coincide with profound and divisive moral conflict" (p. 207). De gustibus non est disputandum — there is no arguing about taste-but the point is precisely that moral judgments are not matters of taste, and that we do not treat disagreements about moral judgments "with the friendly indulgence" that Callan, for instance, extends "to those who foolishly prefer scotch to Irish whiskey" (p. 207).

Some people use the term "relativism" when they mean what I have described as pluralism. Blake et al. (1998) distinguish pluralism from relativism in the following way:

There is a moral view, arguably a coherent one, which some call relativist, that we should cherish and respect genuine moral diversity while fearing moral dogma and pressures toward moral conformity. We are hesitant, though, to use the word relativism here (preferring pluralism), because such a view clearly pulls certain non-negotiable commitments back in by the back door: commitments to, for instance, a certain moral humility and respect for the judgments of others. (p. 9)

The justifiable fear of moral absolutism leads some educators to fear even such minimal standards as moral humility and respect for (which is not the same as agreement with) the judgments of others. Such standards, however, are necessary if we wish to prevent our students from falling into the solipsistic traps of subjective relativism.

Student-teachers in my class have given me some examples from their practica that illustrate the relevance of understanding the difference between preferences and judgments, and between pluralism and relativism. In one elementary classroom, a student declared that, "married people cannot get AIDS, because AIDS is a punishment from God." This is not only a dangerous misunderstanding of the nature of the virus involved, but also a serious moral judgment about people with HIV/AIDS. When expressed in a classroom, this judgment requires a response from a teacher who understands the difference between a judgment and a preference, and who can distinguish stronger from weaker reasons. The response "You are entitled to your opinion" would be entirely inappropriate and miseducative.

The obviously defensive stance “That's just your opinion!" sometimes comes disguised in other forms that can make it harder to recognize. Two such forms are "I respect your view" and "Let's agree to disagree." Both phrases have appropriate uses, even when judgments rather than preferences are involved. In the political arena, for example, a social-democrat might find herself disagreeing with a political opponent about the relative role of personal responsibility. "I respect your view" here might mean, "I respect your legitimacy as political adversary and I recognize the reasons you have provided for your judgments, but at the end of the day, I will still disagree with your view that greater income inequality is justifiable as an incentive." Likewise, "Let's agree to disagree" can usefully exclude a divisive topic that threatens to derail a discussion about another topic. Someone might suggest, "Let's 
agree to disagree for the moment about the possibility of non-dogmatic religious faith so that we can focus on our discussion about the legitimacy of anti-abortion protests outside abortion clinics."

Both phrases, "I respect your view" and "Let's agree to disagree," also get used in the classroom, however, and sometimes in inappropriate ways. If a child remarks that "Indians are poor because they're lazy," then that is not a view to be "respected," nor is it an appropriate moment for an educator to "agree to disagree," no matter how much he or she wishes to stay away from this discussion or get on with a lesson. Such a judgment, when entered into the classroom conversation, must be examined, and in order to do so the educator needs to understand the difference between a judgment and a preference, and be able to distinguish stronger from weaker reasons. In the classroom, we should be happy to agree to disagree about whether chocolate ice cream is preferable to vanilla or the other way around, but when it comes to judgments about issues of "more than slight moral consequence" (Callan, 1997, p. 204), educators have an educative responsibility to help students examine these judgments and the reasons provided for them.

Let me close with a brief consideration of the specific nature of the space that provides the context for this discussion: the classroom. The classroom is not a truly public space, the way in which a public square or park are public spaces. There are restrictions on who can be in the classroom, and there are differences in authority between students and teachers that distinguish their interactions from those of citizens in a public square or park. The classroom is also not a truly private space, however, the way in which someone's home is a private space. Neither teacher nor students have control over the particular students who are assigned to the classroom, and many students are strangers prior to meeting each other in the classroom. If we conceive of education as a social practice that straddles the public and private sphere and that "mediates [the] passage between the specificity of intimate relations and the generalities of the public world" (Grumet, 1988, p. 14), the classroom fulfills a particular role in student transition from the private to the public.

The public world provides encounters with those who hold opinions (both in the sense of preferences and in the sense of judgments) different from one's own. In the classroom, students need to be prepared for such encounters both by learning to justify their own judgments and by learning to examine the judgments and justifications that others provide. If the classroom becomes a space in which a discussion can be shut down by declaring someone's judgment "just their opinion," it does not fulfill its role as a transitional space between the private and the public. Pluralism can only be sustained by an ongoing public conversation about the sets of values that should or should not guide the lives of members of the diverse polity. The refusal to expose one's own opinions to the scrutiny and potential disagreement of others is a refusal to engage in the public qua public. When "that's just my opinion" is used to shield one's views from public scrutiny, or "that's just your opinion" is used to disavow one's responsibility to engage another's views, these phrases do not belong in the classroom. And that is not just my opinion.

\section{References}

Berlin, I. (1998, May 14). My intellectual path. New York Review of Books. Retrieved on February 17, 2007, from http://www.nybooks.com/articles/13853.

Blake, N., Smeyers, P., Smith, R., \& Standish, P. (1998). Thinking again: Education after postmodernism. Westport, CT: Bergin \& Garvey.

Callan, E. (1997). Creating citizens: Political education and liberal democracy. New York: Oxford University Press.

Grumet, M. R. (1988). Bitter milk: Women and teaching. Amherst: The University of Massachusetts Press.

Lyotard, J.F. (1984). The postmodern condition: A report on knowledge (G. Bennington \& B. Massumi, Trans.). Minneapolis: University of Minnesota Press. (Original work published 1979) 


\section{About the author}

Claudia Ruitenberg is an Assistant Professor of Philosophy of Education in the Department of Educational Studies at the University of British Columbia. Her areas of interest include speech act theory and questions of censorship in education, identity construction and identity politics, and gender issues and queer theory. She enjoys teaching philosophically oriented education courses at both the undergraduate and graduate levels, but is growing increasingly exasperated with students who believe that stating an opinion is the same as justifying it. 